\title{
GW23-e1285 EFFECTS OF EXERCISE THERAPY AT THE INTENSITY OF ANAEROBIC THRESHOLD FOR CARDIOPULMONARY FUNCTION IN PATIENTS WITH AMI AFTER PERCUTANEOUS CORONARY INTERVENTION
}

doi:10.1136/heartjnl-2012-302920i.2

Lin Che, Lemin Wang. Tongji Hospital, Tongji University

Objectives The purpose is to investigate the feasibility and safety of aerobic exercise prescription from the individually-based results of cardiopulmonary exercise test (CPET) and influence of aerobic exercise training for cardiopulmonary function in patients with acute myocardial infarction (AMI) after percutaneous coronary intervention (PCI).

Methods 147 consecutive patients with AMI after PCI were divided into exercise group and control group, who finished twice times CPET and followed their rehabilitation programme for 3 months. Patients in the exercise group finished their aerobic exercise therapy based on their individually anaerobic threshold. CPET was measured at the time of discharge, at the end of 3 months, including ventilatory response to exercise and cardiac output changes during exercise.

Results Their heart rate at AT intensity $\left[92 \pm 10\right.$ beat $\left.\cdot \mathrm{min}^{-1}\right]$ was lower than their traditional minimal target heart rate $(105 \pm 6$ $\beta \bullet \mathrm{min}^{-1}$ ) following the exercise test. The abnormal CO response at exercising was found in $38.7 \%$ patients with AMI after PCI, which the CO was maxim when exercising at AT (AT: anaerobic threshold) load and was decreasing after the load was far exceeded the AT load. The $\mathrm{O}_{2}$ consumption $\left(14.0 \pm 4.0 \mathrm{ml} \mathrm{min}^{-1} \mathrm{~kg}^{-1}\right.$ and $\left.20.0 \pm 4.0 \mathrm{ml} \mathrm{min} \mathrm{mg}^{-1} \mathrm{~kg}^{-1}\right)$ and workload $\left(64.2 \pm 20.2 \mathrm{~J} \mathrm{~s}^{-1}\right.$ and 91.0 $\left.\pm 15.3 \mathrm{~J} \mathrm{~s}^{-1}\right)$ at peak level and the $\mathrm{O}_{2}$ consumption $(10.1 \pm 2.4 \mathrm{ml}$ $\min ^{-1} \mathrm{~kg}^{-1}$ and $12.6 \pm 2.9 \mathrm{ml} \mathrm{min}^{-1} \mathrm{~kg}^{-1}$ ) and workload (35.4 $\pm 18.6 \mathrm{~J} \mathrm{~s}^{-1}$ and $42.7 \pm 16.8 \mathrm{~J} \mathrm{~s}^{-1}$ ) at AT level markedly increased than before 3 months in exercise group, and the $\mathrm{O}_{2}$ consumption (14.9 $\pm 3.1 \mathrm{ml} \mathrm{min}^{-1} \mathrm{~kg}^{-1}$ and $18.3 \pm 2.0 \mathrm{ml} \mathrm{min}^{-1} \mathrm{~kg}^{-1}$ ) and workload $\left(64.7 \pm 23.2 \mathrm{~J} \mathrm{~s}^{-1}\right.$ and $\left.79.2 \pm 16.1 \mathrm{~J} \mathrm{~s}^{-1}\right)$ at peak level increased than before 3 months in control group, but their $\mathrm{O}_{2}$ consumption (10.7 


\section{ABSTRACTS}

$\pm 2.4 \mathrm{ml} \mathrm{min}^{-1} \mathrm{~kg}^{-1}$ and $11.0 \pm 2.3 \mathrm{ml} \mathrm{min}^{-1} \mathrm{~kg}^{-1}$ ) and workload $\left(36.7 \pm 21.2 \mathrm{~J} \mathrm{~s}^{-1}\right.$ and $\left.38.1 \pm 21.2 \mathrm{~J} \mathrm{~s}^{-1}\right)$ at AT level had not obvious change ( $p>0.05)$. After 3 months aerobic exercise therapy, patients with abnormal $\mathrm{CO}$ response during exercising recovered normal exercise $\mathrm{CO}$ response in exercise group (12 patients recovered normal exercise $\mathrm{CO}$ response in 17 patients with primitively abnormal CO response) and control group (2 patients recovered in 14 patients with abnormal CO response) $\left(\mathrm{X}^{2}=9.827, \mathrm{p}=0.002\right)$.

Conclusions AT exercise intensity is safe and scientific and effective, which is basis of aerobic exercise prescription. Exercise therapy at the intensity of anaerobic threshold can improve oxygen capacity and exercise endurance and correct abnormal exercise $\mathrm{CO}$ response, which is safe and effective and should be better recommended for patients with AMI after PCI. 